221 近似法によるStatic画像での短時間測定の検討 東北大学医学部附属病院・放射線部 細貝良行

【目的】核医学の理想的な系では，RIが取り込まれた部位から測定さ れる放射線量は単位時間 $(\Delta \mathrm{t})$ あたり一定である。このことは正確な $\Delta \mathrm{t}$ おびその時のCount数を把握することにより必要時間後のCount 数が推定されることを示す。しかしながら，臨床における測定計で は散乱線，装置特性などの外乱が発生し一定の測定值は当然得られ ない。そこでわれわれは $\Delta \mathrm{t}$ なたりのCount数を複数個連続して把握 することで必要時間後のCount数を近似法にて推定し得る可能性を基 礎的検討として技術学会第 41 回東北部会にて報告した，今回はさら にその発展としての報告を行う.

【方法】 ${ }^{99 m} \mathrm{Tc}$ を封入したファントムを 1 秒ごとに 5 分間(計 300 フレー ム)測定したデー夕を基に各フレームを時系列で並べ替えし，時間と Countの変化からすべてのピクセルにおいて近似式を作成し，その近 似式を基に必要時間後のデータの推定を行い短時間測定を試みる. マトリックスサイズは256×256とし67 $\mathrm{Ga}$ 㧍よび臨床画像を加味し発展 性を考察する．解析処理はVisualC++Ver6.0を使用し自作する。

【結果】必要時間後のデータが推定できることで短時間測定の可能性 が示唆された. Count数が全体的に増幅されることによりWindow 幅，Levelの設定が可能となり，通常より多階調の出力が可能となっ た。

222 モバイル型ガンマカメラを用いた甲状腺ヨウ素掑取率測定 野口記念会野口病院·放射線科村上智紀，丹生正一，猪俣昌弘 野口靖志, 新谷知彦、下東吉信, 宮原純徳

八曰会藤本早鈴病院・第一放射線科 西井龍一

【目的】Digirad 2020tc Imager ${ }^{\mathrm{TM}}(2020 \mathrm{tc})$ は，世界で初めて半導体検出 器を用いたモバイル型ガンマカメラである。今回，2020tcを用いた 甲状腺ヨウ素㠌取率測定をPhantom Studyにおいて検討した。

【方法】当院で作成した甲状腺Phantom(内容量 $42 \mathrm{ml}$ )に，10.4，31.3， $62.5,125.0 \mathrm{kBq} / \mathrm{ml}$ 程度の ${ }^{123} \mathrm{I} \mathrm{NaI}$ 溶液を入れた。これは ${ }^{123} \mathrm{I} \mathrm{NaI} 7.4 \mathrm{MBq}$ を投与した場合に，甲状腺ヨウ素掑取率 (up take)がそれぞれ6.0, 17.5，35.0，70.0\%程度となるように想定したものである。標準線源

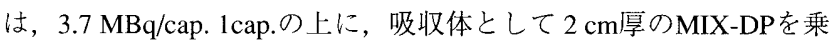
せたものを使用した。これらを2020tcとAnger型ガンマカメラである GCA-7100A (東芝) を使用し，それぞれPlanar像を10分間で撮像し た. CollimatorはLEAP(GCA-7100AはLEGP) とLEHRを使用した。得 られたシンチグラムでROIのcountを測定し，up takeを算出した。

【結果】2020tcでの測定值は，LEAP Collimatorの場合は，それぞれ 5.1，14.6，28.3，57.7\%であった. LEHR Collimatorの場合は，そ れぞれ5.2，14.8，30.3，58.9\%であったAnger型でのup takeは, LEGP Collimatorの場合は，それぞれ4.3，12.3，25.7，52.3\%であっ た. LEHR Collimatorの場合は，それぞれ4.5，13.3，27.4，53.6\%で あった。

【まとめ】今回の実験により得られた測定值は，すべて理想值よりも 低い值となった。これは，標準線源がカプセルであり，点線源の形 状に近かったためだと考える．2020tcでの測定值は，LEAP CollimatorよりもLEHR Collimatorの方が高い值となった，また， Anger型での測定値も，LEGP CollimatorよりもLEHR Collimatorの方 が高い值となった。これは, 隔壁の厚さがLEAPまたはLEGP CollimatorよりもLEHR Collımatorの方が薄く, 散乱線の影響が大き かったためだと考える。2020tcの方がAnger型よりも理想値に近い值 が得られた。これは, Anger型は一つのシンチレータにより放射線 が検出されるのに対し，2020tcの検出器が $3 \mathrm{~mm}$ 四方の検出素子が 64×64個配列され，それぞれにより放射線が検出されるためだと考 える．また，ROIの取り方などによっても測定值の变動があると思 われるため, 今後さらに検討が必要であると考える。

【結語】モバイル型ガンマカメラによる甲状腺ヨウ素撕取率測定は有
用であるが，今後さらなる検討が必要だと考える。

223 センチネル検出用小型 $\gamma$ カラの甲状腺掑取率測定装置への 応用

千葉県がんセンター・核医学診療部 木下富士美, 日吉和久 市原裕紀，別府俊子

千葉県がんセンター・物理室 成田雄一郎

安西メディカル(株) 流王英樹、池谷憲生

【目的】甲状腺ヨード摄取率測定検査は最も早くから始められた核医 学検査法の一つである. 最近ではカメラを用いた方法も行われてい るが, 従来からはシンチレーションカウンタを用たBフィルタ法が 行われている. 今回七ンチネル検出用小型 $\gamma$ カメラ (eZ-SCOPE) 購入

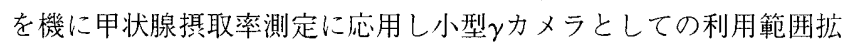
大を試みた。

【方法】センチネル検出用の半導体検出器を装備したThyroldo Uptake System (AZ-800-CZT) としての等感度分布測定, 甲状腺摂取率の信頼 性, 臨床使用, 沉用性などにつき検討した。

【結果】検出器支持，PC搭載型のキャス夕一付き台車を作成した。 ${ }^{123}$ I カプセルを用いての甲状腺ファントムによる甲状腺撕取率測定值の 信頼性では測定值士 $1 \%$ 以内であった。摂取率測定装置としての等 反応曲線からは従来のシンチレーションカウンタ法の測定条件と同 等で良いと判断した，RIセンチネルリンパ節検出法はまだ保険診療 が認装置購入が困難な施設が多い.今後eZ-SCOPEが甲状腺摂取率 測定装置やダイバジングコリメータなどの開発により, 小臓器撮像 等の用途拡大(モバイルカメラとしての利用)が多少なりとも装置導 入を容易とすると思われる。

224 RIS拡張機能としての核医学業務支援システム構築と運用 聖路加国際病院·放射線科 熱田雅城，根津正次，細谷和彦，江田裕介 横河電機(株) 鏑木善誉, 竹村聡之介

【目的】非密封放射性医薬品を取り扱う施設において，放射性医薬品 の管理は必須業務となっている，今回，HIS，RISの更新を機にRIS 拡張機能として核医学業務支援システムを構築し, 運用を開始した ので報告する.

【方法】本システムはRIS (横河電機(株))の一部として, 放射性医薬品 の管理を行うためのシステムである. 本院では従来既敝のシステム を購入し使用していたが，ハードも含めると高額となり，また，入 力など多くの手間が必要であった，今回のシステムはRISの端末上 で動作し，必要な患者情報，検查情報などをRISから取得可能であ り放射性医薬品，核種などをマスター登録する事で手入力部分を減 らし簡便な操作で管理業務を行うことを可能にした。この新システ ムの有用性を既存のシステムなどと比較し検討する.

【考察】本システムにより，放射性医薬品使用に関する必要書類の作 成，使用量などの管理業務が簡便に行えるようになった。核医学管 理業務を行ううえで本システムが大きな役割を果たすものと考え る.

\section{5 フィルムレスにおける画像の誤送信}

国立成育医療センタ一・放射線診療部 細越光夫，加賀山智史 梶谷敏郎

【目的】当施設は電子カルテ, 完全フイルムレス運用で平成 14 年 3 月 に開院した。画像は各モダリティからPACS, 電子カルテの画像 サーバに送信される.当院では電子カルテに送信した画像は上書き されないシステムであるため, 画像を確認してから送信しているが ヒューマンエラーによる誤送信は発生している。今回一般撮影にお いて原因などを調査し検討したので報告する。

【方法】平成14年度の 1 年間で技師からの報告, 読影医, 依頼医から 指摘を受けた事例について調查した。 